\title{
Effect of Water Exchange and Mechanical Aeration on Grow-out of the Amazon River Prawn in Ponds
}

\author{
JANAINA M. KIMPARA ${ }^{1}$ \\ Embrapa Meio Norte, BR 343, km 35, Zona Rural, CEP 64200-970, Parnaíba, PI, Brazil \\ Alexandre A. O. Santos \\ Aquaculture Center, Soa Paulo State University, Campus de Rio Claro, Av. 24 A, 1515, Bela \\ Vista, CEP 13506-906, Rio Claro, SP, Brazil \\ WAGNER C. VALENTI \\ Soa Paulo State University, Campus Experimental do Litoral Paulista, Praça Infante Dom \\ Henrique s/n, Parque Bitaru, CNPq, CEP 11330-900, São Vicente, SP, Brazil
}

\begin{abstract}
Exchange and aeration of pond water are common practices in semi-intensive freshwater prawn culture, but there is lack of scientifically based information on the results. We evaluated the effects of water flow through the ponds and mechanical aeration in semi-intensive cultures of Macrobrachium amazonicum. A total of 40 juveniles $/ \mathrm{m}^{2}$ were stocked for 4 mo in 12 earthen ponds. Four randomly assigned treatments were applied: no aeration + no water exchange $(\mathrm{NN})$, diurnal aeration + no water exchange (DA), nocturnal aeration + no water exchange (NA), and continuous water flow (CF). Temperature, pH, total suspended solids, and soluble orthophosphate in the water column did not differ among treatments. Dissolved oxygen (DO) concentrations in ponds with nocturnal aeration were significantly higher than in other treatments. The concentration of inorganic nitrogen was significantly higher in the CF treatment, whereas organic nitrogen was higher in treatments NN, DA, and NA. This suggests that primary production is higher in static ponds. Thermal stratification started at $0900 \mathrm{~h}$, and the maximum difference between surface and bottom temperature varied from 1.5 (CF) to $2.8 \mathrm{C}(\mathrm{NN})$. The difference between DO levels in the surface and bottom water of the ponds began to appear at $0800 \mathrm{~h}$ and varied from 0.50 (CF) to $5.23 \mathrm{mg} / \mathrm{L}(\mathrm{NN})$. Diurnal aeration and high continuous water flow were efficient in disrupting the stratification. No significant difference was found for survival, mean weight, apparent feed conversion rate, and productivity among treatments. Thus, disrupting water stratification, aerating ponds at night, or exchanging the pond water are ineffective in Amazon River prawn farming in semi-intensive systems, at least for stocking densities lower than 40 individuals $/ \mathrm{m}^{2}$. About $1000 \mathrm{~kg}$ of Amazon River prawn can be produced in static ponds with no aeration in approximately 4 mo. This management strategy saves water and energy and reduces production costs.
\end{abstract}

Macrobrachium amazonicum is the native freshwater decapod of greatest economic importance in the eastern South American subcontinent (Maciel and Valenti 2009). It is a valuable product for human consumption and also as bait for sport fishing, an ornamental pet, and live food for carnivorous ornamental fish (Maciel and Valenti 2009; Valenti et al. 2011; Marques and Moraes-Valenti 2012).

\footnotetext{
${ }^{1}$ Corresponding author.
}

Its production is still mainly based on wild fisheries, but aquaculture has recently been initiated (Marques and Moraes-Valenti 2012). Production of $1000 \mathrm{~kg} / \mathrm{ha}$ is easily obtained in a 4-mo grow-out period in earthen ponds, and can exceed $5000 \mathrm{~kg} / \mathrm{ha} / \mathrm{yr}$ under ideal conditions (Moraes-Valenti and Valenti 2007).

Pond production is limited by many factors, such as accumulation of potential toxic by-products (i.e., $\mathrm{NH}_{3}$ ) and reduction in the dissolved oxygen (DO) level at night and water 
stratification in the afternoon (which can reduce temperature and DO near the bottom). Therefore, management practices that reduce the effect of these limiting factors increase the system carrying capacity, allowing intensification, which increases productivity and may save space. Nonetheless, intensification practices have been introduced in semi-intensive systems without prior analyses of limiting factors. This may increase financial and environmental costs, with no corresponding increase in yield. Therefore, it is important to study the factors that limit production in semi-intensive systems and the efficiency of management practices intended to increase intensification.

Water exchange and mechanical aeration have been used to increase carrying capacity in ponds. However, fresh water is scarce in many areas, and recently has become limiting even in some wet regions. The use of aeration may decrease water consumption, but is expensive and consumes much energy. Thus, management practices that use water in an efficient and conservative way may save this important resource for other sectors, whereas the rational use of aerators may reduce production costs and save energy.

Water exchange by continuous flow through the ponds is widely recommended in the literature and is generally practiced by prawn farmers around the world to prevent oxygen depletion and reduce the toxic effects of inorganic nitrogen (New 2002; Valenti et al. 2010). Nevertheless, this practice may be unnecessary in semi-intensive systems or even be inefficient for maintaining suitable water quality (Boyd and Tucker 1998). Probably, its effectiveness depends on the flow rate. Toxic by-products may also be reduced by their transformation within the ponds, and oxygen may be regenerated by primary production. By reducing the water exchange rate, the retention time in the ponds increases, allowing natural processes to assimilate residuals (Boyd et al. 2007) and produce oxygen. Thus, increasing the retention time reduces pollutants and the volume of effluents, and consequently the contaminants discharged into the environment. Aerators may be useful in low-water exchange ponds because they mix water, reducing vertical stratification of temperature and chemical substances and preventing oxygen depletion.

Although water exchange and water aeration are common practices in semi-intensive freshwater prawn culture, scientifically based information on these management strategies is scarce. The purpose of this study was to evaluate the effects of water flow through the ponds and aeration in semi-intensive Amazon River prawn farming. This should contribute toward establishing more sustainable management of water resources and energy use in prawn aquaculture.

\section{Materials and Methods}

The study was conducted in the Crustacean Sector of the Aquaculture Center, at São Paulo State University, Brazil $\left(21^{\circ} 15^{\prime} 22^{\prime \prime} \mathrm{S}\right.$, $\left.48^{\circ} 18^{\prime} 48^{\prime \prime} \mathrm{W}\right) . \quad$ M. amazonicum post-larvae (PL) were obtained from broodstock descended from wild animals captured in Pará State $\left(01^{\circ} 14^{\prime} 30^{\prime \prime} \mathrm{S}, 48^{\circ} 19^{\prime} 52^{\prime \prime} \mathrm{W}\right)$ in 2001. Early metamorphosed PL were stocked in indoor nursery tanks at a density of $7 \mathrm{PL} / \mathrm{L}$ for 15 $\mathrm{d}$ and then stocked in nursery ponds at 200 $\mathrm{PL} / \mathrm{m}^{2}$ for $30 \mathrm{~d}$. Juveniles $(0.01 \mathrm{~g})$ were then stocked in 120.01-ha earthen ponds at a density of 40 individuals $/ \mathrm{m}^{2}$. After 4 mo (February to May 2008), all ponds were drained and totally harvested.

A fully randomized experimental design with four treatments and three replicates was applied. Treatments were no aeration + no water exchange $(\mathrm{NN})$, diurnal aeration + no water exchange (DA), nocturnal aeration + no water exchange (NA), and continuous water flow (CF). Treatment DA ponds were aerated from 1400 to $1600 \mathrm{~h}$ to reduce thermal stratification. Treatment NA ponds were aerated from 2300 to $0500 \mathrm{~h}$ to supply DO lost in respiration during the night. The aerators used were Aquahobby B-500, 373 W (Bernauer Aquacultura, Blumenau, Brazil). Treatment CF ponds had continuous water exchange at a rate of approximately $35 \% / \mathrm{d}$.

The ponds were filled with hypereutrophic water from a reservoir that recycled aquaculture 
pond effluents. This nutrient-rich water has similar characteristics to the water found in aquaculture ponds. Because water is a scarce resource and high-quality water is destined for other purposes than aquaculture, the use of nutrient-rich water is a feasible alternative for aquaculture (Kimpara et al. 2011). The prawns were fed a commercial sinking pelletized diet with $35 \%$ crude protein in two equal portions a day, at 0800 and $1600 \mathrm{~h}$. Prawn biomass in the ponds was estimated every 3 wk by weighing animals on a Marte model A 500 balance $(0.01$ g; Marte Científica, Santa Rita do Sapucaí, Brazil). Daily feeding rate was initially $9 \%$ of prawn biomass. This rate was reduced by $2 \%$ each month, reaching 3\% in the last week. The amount of food was adjusted weekly, based on $1 \%$ estimated mortality and $20 \%$ weight gain per week. Feeding was reduced by half when DO was below $3.5 \mathrm{mg} / \mathrm{L}$ in the morning.

Water temperature and DO were monitored daily at $0700 \mathrm{~h}$, and water exchange rate and $\mathrm{pH}$ were measured weekly at $1500 \mathrm{~h}$. The water exchange rate was measured at the pond entrance using a graduated bucket. Temperature and DO were measured using a digital YSI model 55 oxygen meter (Yellow Springs Instruments, Yellow Springs, OH, USA), and the $\mathrm{pH}$ was determined using a digital YSI model 63 pH meter (Yellow Springs Instruments). A diurnal variation analysis was performed to evaluate the effect of water exchange and mechanical aeration on temperature and DO stratification in the ponds. These variables were determined at the surface and bottom of ponds at 1-h intervals for $24 \mathrm{~h}$, using an YSI model 55 oxygen meter (Yellow Springs Instruments). Measurements were taken once a month for 3 mo.

Possible accumulation of by-products in the ponds was analyzed in the water column and the sediment. Total suspended solids (TSS), soluble orthophosphate, inorganic nitrogen (Nammonia $+\mathrm{N}$-nitrate $+\mathrm{N}$-nitrite), and organic nitrogen (Kjeldahl nitrogen- $\mathrm{N}$-ammonia) were determined in water samples taken approximately $10 \mathrm{~cm}$ above the pond bottom, using a van Dorn limnological bottle. All variables were evaluated weekly at $1500 \mathrm{~h}$. Soluble orthophosphate was determined by the stannous chloride method; N-total ammonia was determined by the phenate method, N-nitrite by colorimetric, and $\mathrm{N}$-nitrate by cadmium reduction methods (APHA 2005).

Before stocking, the pond bottoms were marked using five brick tiles (at the corner and in the center) so that sediments accumulated during the rearing cycle could be sampled. Five sediment samples per pond were taken and combined for analyses of organic matter, total phosphorus, and organic carbon. The samples were dried at $60 \mathrm{C}$ to constant weight, ground, and homogenized. Then, organic matter and total phosphorus were determined. Organic matter was determined by incinerating samples in a muffle furnace at $550 \mathrm{C}$ for $5 \mathrm{~h}$. Phosphorus concentration in sediments was determined by perchloric acid digestion followed by the colorimetric ascorbic acid method (APHA 2005). The amount of carbon originally in the samples was determined by dividing the quantity of organic matter by the correction factor 1.82 (Pereira et al. 2006).

At harvest, all animals were counted and a random sample of $10 \%$ of all prawns was taken from each pond to determine individual weight. Survival, mean weight, productivity, and apparent feed conversion rate were determined. As no pattern of temporal variation was detected $(P>0.05)$, data obtained in all weeks in three ponds of each treatment were grouped for water quality analysis by analysis of variance (ANOVA). Survival data were previously arcsine-transformed, but the original values are presented to facilitate interpretation. All data were tested for normality (Shapiro-Wilk) and homoscedasticity (Brown-Forsythe). As both conditions were satisfied, means were compared by one-way ANOVA, $F$-test. Statistical analyses were carried out in SAS software (version 9.0). Means were considered significantly different when $P<0.05$. When significant differences were detected among treatments, means were compared by the Duncan test.

\section{Results}

Thermal stratification began to develop at 0900-1000 $\mathrm{h}$ in all ponds (Fig. 1), with the 
most intense stratification occurring around 1300-1400 h. The maximum difference between surface and bottom temperatures was observed in ponds with no aeration and no water exchange $(\mathrm{NN})$ and was $2.8 \mathrm{C}(1400 \mathrm{~h})$. In ponds with diurnal aeration (DA), the maximum difference was $2.0 \mathrm{C}$ at $1300 \mathrm{~h}$, just before the aerator was turned on. In ponds with nocturnal aeration (NA), this value was $2.5 \mathrm{C}$ at $1400 \mathrm{~h}$; and in ponds with continuous water flow $(\mathrm{CF})$, it was $1.5 \mathrm{C}$ at the same time of day (Fig. 1). A difference of less than $0.5 \mathrm{C}$ between surface and bottom temperatures was found from 2100 to $0900 \mathrm{~h}$ on the following day in treatment $\mathrm{NN}$ (Fig. 1). In treatments $\mathrm{DA}, \mathrm{NA}$, and $\mathrm{CF}$, this difference was found from 1400,1900 , and $2300 \mathrm{~h}$ to $0900-1000 \mathrm{~h}$ on the following day, respectively (Fig. 1).

In treatment DA, thermal stratification started at $1000 \mathrm{~h}$, when the difference between surface and bottom temperatures was $0.8 \mathrm{C}$ (Fig. 1). This difference varied from 0.1 to 0.2 while the aerator was running (1400-1600 h), and water temperature remained homogeneous until $1000 \mathrm{~h}$ on the following day (Fig. 1). In treatment NA, stratification started at $1000 \mathrm{~h}$; from $1900 \mathrm{~h}$ onward, the difference between surface and bottom temperatures was less than $0.5 \mathrm{C}$ and there was no difference when the aerator was turned on at $2300 \mathrm{~h}$ (Fig. 1).

The difference between DO concentrations in surface and bottom water of the ponds started at $0800 \mathrm{~h}$ in all treatments (Fig. 2). The peak difference was found at $1700 \mathrm{~h}$ in treatment $\mathrm{NN}(5.23 \mathrm{mg} / \mathrm{L})$, at $1200 \mathrm{~h}$ in treatment DA $(1.52 \mathrm{mg} / \mathrm{L})$, at $1400 \mathrm{~h}$ in NA (3.61 mg/L), and at $1500 \mathrm{~h}$ in $\mathrm{CF}(0.50 \mathrm{mg} / \mathrm{L})$ (Fig. 2). The difference in DO levels between surface and bottom water of ponds was less than 0.5 $\mathrm{mg} / \mathrm{L}$ at $0100 \mathrm{~h}$ in treatment $\mathrm{NN}$, at $1400 \mathrm{~h}$ in treatment DA, and at $2100 \mathrm{~h}$ in treatment NA. In treatment $\mathrm{CF}$, the difference was always less than $0.5 \mathrm{mg} / \mathrm{L}$ (Fig. 2).

No significant difference was found among treatments and between treatments and inlet water concerning temperature, $\mathrm{pH}$, TSS, and soluble orthophosphate in the water column (Table 1). DO concentrations in the inlet water and in ponds with nocturnal aeration did not

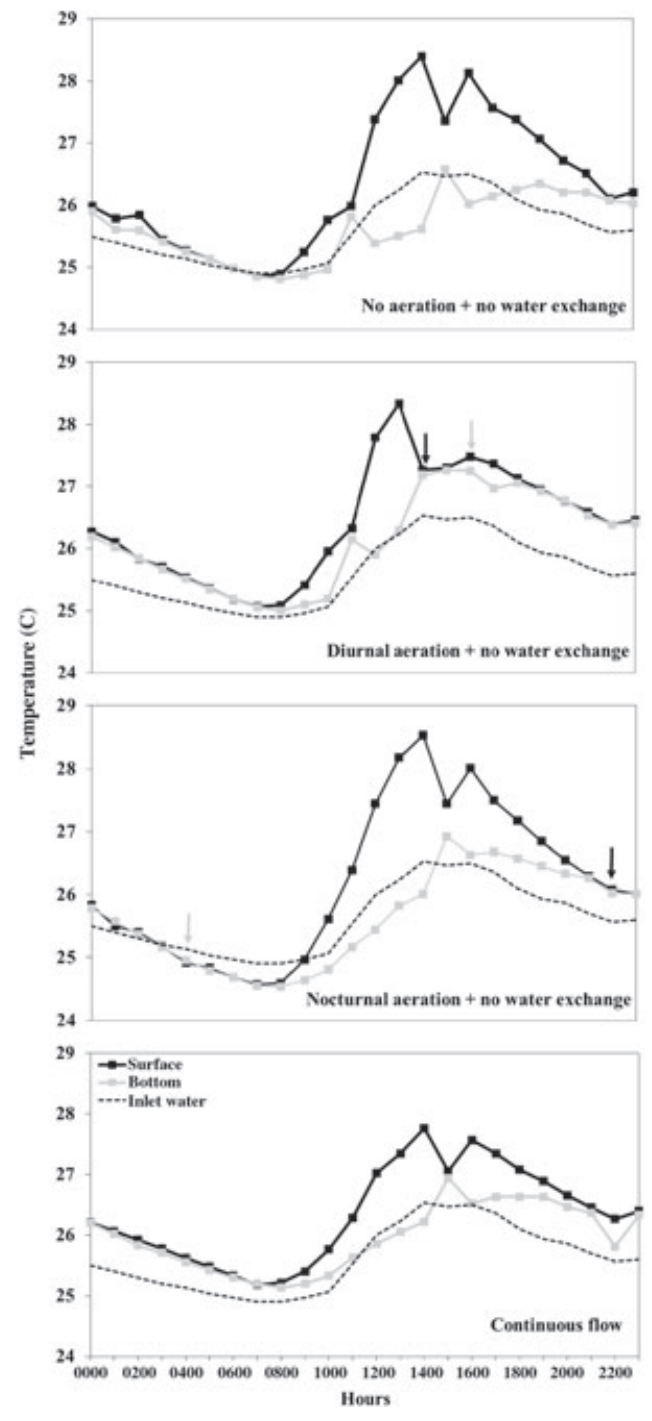

FIGURE 1. Variation in temperature throughout the day in inlet water and ponds subjected to treatments of: no aeration + no water exchange, diurnal aeration, nocturnal aeration, and continuous flow. Each value corresponds to the mean of measurements made on $3 d$, with an interval of 1 mo between measurements. Black arrow indicates when aerator was turned on and gray arrow indicates when aerator was turned off.

differ significantly from each other, whereas both differed from treatments NN, DA, and $\mathrm{CF}$ (Table 1). The concentration of inorganic nitrogen was significantly higher in the inlet water and in the CF treatment, and lower in treatments $\mathrm{NN}$ and DA (Table 1). On the 

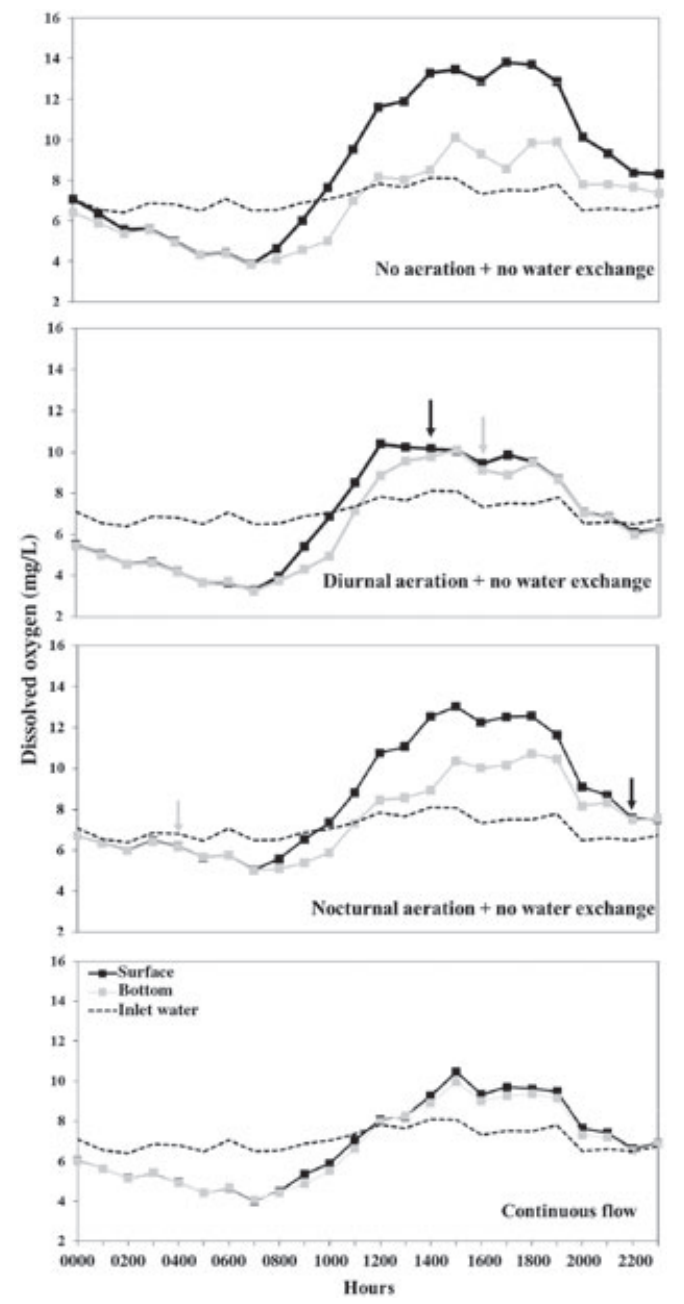

FIGURE 2. Variation in dissolved oxygen throughout the day in inlet water and ponds subjected to treatments of: no aeration + no water exchange, diurnal aeration, nocturnal aeration, and continuous flow. Each value corresponds to the mean of measurements made on $3 d$, with a 1-mo interval between measurements. Black arrow indicates when aerator was turned on and gray arrow indicates when aerator was turned off.

other hand, organic nitrogen was higher in treatments NN, DA, and NA (Table 1). No significant difference was observed in organic matter, total phosphorus, and organic carbon accumulation in the bottom sediment of ponds in any treatment (Table 2).

There were no significant differences in survival, mean weight, apparent feed conversion rate, and productivity of the prawns among treatments (Table 3). Mean survival varied from $63.1(\mathrm{NN})$ to $69.7 \%(\mathrm{CF})$. Mean weight varied from $3.62(\mathrm{NN})$ to $4.12 \mathrm{~g}(\mathrm{CF})$. Apparent feed conversion rate varied from $3.9(\mathrm{CF})$ to $4.9(\mathrm{NN})$. Mean productivity varied from 0.92 $(\mathrm{NN})$ to $1.14 \mathrm{t} / \mathrm{ha}(\mathrm{CF})$.

\section{Discussion}

The use of a static system, diurnal or nocturnal aeration, or high water flow did not significantly affect the prawn performance or the quantity and quality of sediment settled on the pond bottom, and also did not change the temperature, $\mathrm{pH}$, and TSS in the water column. DO was higher in the inlet water and in the nocturnally aerated ponds. High water flow ponds showed higher levels of inorganic nitrogen and lower levels of organic nitrogen, suggesting a reduction in photosynthesis. The water parameter values obtained in the present experiment are similar to those found in previous studies in the grow-out phase (Keppeler and Valenti 2006, Moraes-Riodades et al. 2006, Kimpara et al. 2011) and in natural habitats of $M$. amazonicum (Maciel and Valenti 2009). Therefore, we presume that pond water quality was within the adequate range for farming this species.

Thermal stratification occurred in all treatments, despite the shallow depth of the ponds (ca. $1.20 \mathrm{~m}$ ). Stratification may subject prawns to lower temperatures and DO because they live in the bottom of the pond. The thermocline may be disrupted naturally by strong wind or rain. In the present experiment, it was disrupted by the mechanical action of aerators turned on during the day and by the high-flow water exchange. Both practices mixed the warmer, oxygen-rich surface water with the bottom water, increasing the temperature and available DO in the bottom stratum of the ponds. Continuous water flow with high exchange rate was the most efficient method to prevent stratification during the entire day. The water quality in the ponds in the CF treatment was similar to the inlet water, which suggests that the effluents were similar to the water supplied. This similarity may be due to the use of hypereutrophic water and the high turnover rate. Thus, the large volume of 
TABLE 1. Means ( $\pm S D$ ) of limnological variables of inlet water (I) and ponds subjected to treatments of: no aeration + no water exchange (NN), diurnal aeration (DA), nocturnal aeration (NA), and continuous flow (CF). Different letters in the same column indicate that means differ significantly $(\mathrm{P}<0.05)$ by analysis of variance. The number of sample units is $11(\mathrm{~N}=11)$ for inlet water and $33(\mathrm{~N}=33)$ for each treatment.

\begin{tabular}{lccccccc}
\hline & Temp. $(\mathrm{C})$ & $\mathrm{DO}(\mathrm{mg} / \mathrm{L})$ & $\mathrm{pH}$ & $\mathrm{TSS}(\mathrm{mg} / \mathrm{L})$ & $\mathrm{PO}_{4}(\mu \mathrm{g} / \mathrm{L})$ & Inorganic nitrogen $(\mu \mathrm{g} / \mathrm{L})$ & Organic nitrogen $(\mu \mathrm{g} / \mathrm{L})$ \\
\hline $\mathrm{I}$ & $25.7 \pm 2.0$ & $7.7 \pm 2.4^{\mathrm{a}}$ & $8.0 \pm 0.4$ & $16.6 \pm 26.5$ & $2.2 \pm 2.0$ & $628.5 \pm 300.0^{\mathrm{a}}$ & $527.6 \pm 295.3^{\mathrm{b}}$ \\
$\mathrm{NN}$ & $25.9 \pm 2.7$ & $5.2 \pm 2.6^{\mathrm{b}}$ & $8.4 \pm 0.6$ & $78.7 \pm 105.1$ & $4.3 \pm 6.8$ & $176.2 \pm 164.9^{\mathrm{c}}$ & $1024.3 \pm 1178.8^{\mathrm{ab}}$ \\
$\mathrm{DA}$ & $25.6 \pm 2.9$ & $4.8 \pm 2.0^{\mathrm{b}}$ & $8.5 \pm 0.7$ & $72.6 \pm 63.2$ & $4.3 \pm 5.0$ & $204.0 \pm 206.3^{\mathrm{c}}$ & $1423.1 \pm 1523.2^{\mathrm{a}}$ \\
$\mathrm{NA}$ & $26.1 \pm 2.6$ & $6.8 \pm 2.3^{\mathrm{a}}$ & $8.3 \pm 0.5$ & $74.7 \pm 84.4$ & $5.6 \pm 9.8$ & $434.9 \pm 228.4^{\mathrm{b}}$ & $1007.7 \pm 789.2^{\mathrm{ab}}$ \\
$\mathrm{CF}$ & $26.1 \pm 2.4$ & $5.3 \pm 2.0^{\mathrm{b}}$ & $8.3 \pm 0.6$ & $43.7 \pm 59.6$ & $6.0 \pm 10.6$ & $473.0 \pm 209.3^{\mathrm{ab}}$ & $751.5 \pm 857.7^{\mathrm{b}}$ \\
\hline
\end{tabular}

$\mathrm{DO}=$ dissolved oxygen; Inorganic nitrogen $=$ total ammonia + nitrite + nitrate $; \mathrm{PO}_{4}=$ soluble orthophosphate; Temp. $=$ temperature; $\mathrm{TSS}=$ total suspended solids.

TABLE 2. Means $( \pm S D)$ of organic matter, total phosphorus, and organic carbon accumulated in sediment of ponds during the rearing cycle in treatments of: no aeration + no water exchange $(N N)$, diurnal aeration (DA), nocturnal aeration (NA), and continuous flow (CF). There was no significant difference among treatments according to analysis of variance $(\mathrm{P}>0.05)$. Values correspond to the mean of three ponds per treatment.

\begin{tabular}{lccc}
\hline & $\begin{array}{c}\text { Organic matter } \\
\left(\mathrm{kg} / \mathrm{m}^{2}\right)\end{array}$ & $\begin{array}{c}\text { Total phosphorus } \\
\left(\mathrm{kg} / \mathrm{m}^{2}\right)\end{array}$ & $\begin{array}{c}\text { Organic carbon } \\
\left(\mathrm{kg} / \mathrm{m}^{2}\right)\end{array}$ \\
\hline $\mathrm{NN}$ & $11.4 \pm 5.7$ & $2.0 \pm 1.4$ & $6.2 \pm 3.1$ \\
$\mathrm{DA}$ & $9.5 \pm 2.5$ & $1.4 \pm 0.4$ & $5.2 \pm 1.4$ \\
$\mathrm{NA}$ & $11.4 \pm 5.1$ & $1.8 \pm 0.8$ & $6.3 \pm 2.8$ \\
$\mathrm{CF}$ & $13.6 \pm 1.4$ & $2.7 \pm 0.3$ & $7.5 \pm 0.8$ \\
\hline
\end{tabular}

TABLE 3. Means $( \pm S D)$ of survival, mean weight, apparent feed conversion rate, and productivity of prawns subjected to different regimes of water exchange and aeration. Means did not differ among treatments.

\begin{tabular}{lcccc}
\hline Treatments & $\begin{array}{c}\text { Survival } \\
(\%)\end{array}$ & $\begin{array}{c}\text { Mean } \\
\text { weight } \\
(\mathrm{g})\end{array}$ & $\begin{array}{c}\text { Productivity } \\
(\mathrm{t} / \mathrm{ha})\end{array}$ & $\begin{array}{c}\text { Apparent } \\
\text { feed } \\
\text { conversion }\end{array}$ \\
\hline $\mathrm{NN}$ & $63.1 \pm 4.3$ & $3.62 \pm 0.85$ & $0.92 \pm 0.24$ & $4.9 \pm 1.8$ \\
$\mathrm{DA}$ & $65.8 \pm 9.7$ & $3.66 \pm 0.67$ & $0.95 \pm 0.05$ & $4.0 \pm 0.3$ \\
$\mathrm{NA}$ & $63.9 \pm 5.0$ & $3.95 \pm 0.19$ & $1.01 \pm 0.08$ & $4.7 \pm 1.7$ \\
$\mathrm{CF}$ & $69.7 \pm 5.5$ & $4.12 \pm 0.55$ & $1.14 \pm 0.07$ & $3.9 \pm 0.5$ \\
\hline
\end{tabular}

$\mathrm{CF}=$ continuous flow; $\mathrm{DA}=$ diurnal aeration; $\mathrm{NA}=$ nocturnal aeration; $\mathrm{NN}=$ no aeration + no water exchange.

water flowing through the pond may not represent water consumption. Besides, when water is supplied by gravity, the high-flow system does not require energy for pumping, which is an advantage over the use of aerators.

Nocturnal aeration is widely used by aquaculture farmers to supply oxygen at night.
Nevertheless, it was not advantageous in this study, in which the intensification level was $<100 \mathrm{~g} / \mathrm{m}^{2}$. Although higher DO concentrations were observed in the NA treatment, there was no gain in production. Moreover, usage of aerators incurs extra expenses for the purchase and installation of the equipment and consumption of energy. Nevertheless, the use of aerators during the night may be effective in moreintensive systems. In these cases, the benefits of using aerators or a high water exchange rate should be assessed according to the availability and local costs of water and electric power.

The treatments of no aeration + no water exchange and diurnal aeration resulted in the lowest accumulation of inorganic nitrogen and the highest accumulation of organic nitrogen in the water column. This suggests that primary production increased, with assimilation of inorganic nitrogen from the inlet water, feed wastes, and prawn metabolic residuals. In addition, carbon dioxide is sequestered from the environment. Thus, inorganic nutrients are recovered to the food web of heterotrophic organisms. Hence, polyculture of the Amazon River prawn together with a phytoplanktophagous fish in static ponds may be advantageous. Inorganic and organic nitrogen concentrations in treatment $\mathrm{CF}$ did not differ from those in the inlet water. This indicates that high water flux may slow phytoplankton development, although nutrients are available in the water (soluble orthophosphate and inorganic nitrogen).

Survival, prawn growth, and productivity were not affected by the homogenizing of the pond water. Because the prawn growth 
was less than expected, the animals were being overfed, which was demonstrated by the high feed conversion rate $(>3)$. Thus, the disruption of thermal stratification and the possible temperature and DO increase near the pond bottoms do not improve the performance of the Amazon River prawn. In this study, productivity was similar to levels previously found in $M$. amazonicum farming (stocking 40 individuals $/ \mathrm{m}^{2}$ and using pond water exchange) by Moraes-Valenti and Valenti (2007), Nogueira (2008) and Preto et al. (2011), who obtained $1.283,1.174$ and 1.032 t/ha, respectively. Therefore, considering the efficiency of water and energy use, the best alternative for $M$. amazonicum farming in biomass up to approximately $100 \mathrm{~g} / \mathrm{m}^{2}$ is the system with no water exchange and no aeration. This result differs from the usual practice in freshwater prawn culture, in which the systems use water exchange rates of $3-35 \%$ (New 2002; Boyd and Zimmermann 2010). Nevertheless, the use of aerators may be appropriate in regions with a wider range of daily temperatures, in more-intensive culture conditions (e.g., high stocking densities), or when the inlet water is poor in DO or very rich in organic matter. In these cases, aerators may be replaced by high-flow water exchange, if there is abundant water with a gravity flow.

In conclusion, disrupting water stratification, aerating ponds at night, or exchanging pond water is ineffective in Amazon River prawn farming in semi-intensive systems, at least for stocking densities lower than 40 individuals $/ \mathrm{m}^{2}$. In addition, keeping water in ponds for long periods favors carbon fixation and the recovery of inorganic nitrogen, which can be assimilated by cultured animals after it is converted into biomass by the natural biota of the pond. About $1000 \mathrm{~kg}$ of Amazon River prawn can be produced in static ponds with no aeration in approximately 4 mo. This practice saves water and energy and may reduce the production cost.

\section{Literature Cited}

APHA (American Public Health Association). 2005. Standard methods for the examination of water and wastewater. 21st edition APHA, Washington, DC, USA.

Boyd, C. E. and C. S. Tucker. 1998. Pond aquaculture water quality management. Kluwer Academic Publishers, Norwell, Massachusetts, USA.

Boyd, C. E. and S. Zimmermann. 2010. Grow-out systems - water quality and soil management. Pages 239-255 in M. B. New, W. C. Valenti, J. H. Tidwell, L. R. D'Abramo, and M. N. Kutty, editors. Freshwater prawns: biology and farming. WileyBlackwell, Oxford, UK.

Boyd, C. E., C. Tucker, A. McNevin, K. Bostick, and J. Clay. 2007. Indicators of resource use efficiency and environmental performance in fish and crustacean aquaculture. Reviews in Fisheries Science 15:327-360.

Keppeler, E. C. and W. C. Valenti. 2006. Effects of selective harvest of the Amazon River prawn, Macrobrachium amazonicum on pond water, sediment and effluent. Acta Limnologica Brasiliensia 18:110-119.

Kimpara, J. M., F. R. Tito Rosa, B. L. Preto, and W. C. Valenti. 2011. Limnology of Macrobrachium amazonicum grow-out ponds subject to high inflow of nutrient-rich water and different stocking and harvest management. Aquaculture Research 42:1289-1297.

Maciel, C. R. and W. C. Valenti. 2009. Biology, fisheries, and aquaculture of the Amazon River prawn Macrobrachium amazonicum a review. Nauplius 17(2):61-79.

Marques, L. A. M. and P. M. C. Moraes-Valenti. 2012. Current status and prospects of farming the giant river prawn Macrobrachium rosenbergii (De Man 1879) and the Amazon River prawn Macrobrachium amazonicum (Heller 1862) in Brazil. Aquaculture Research 43:984-992.

Moraes-Riodades, P. M. C., J. M. Kimpara, and W. C. Valenti. 2006. Effect of the Amazon River prawn Macrobrachium amazonicum culture intensification on ponds hydrobiology. Acta Limnologica Brasiliensia 18:311-319.

Moraes-Valenti, P. M. C. and W. C. Valenti. 2007. Effect of intensification on grow out of the Amazon River prawn, Macrobrachium amazonicum. Journal of the World Aquaculture Society 38:516-526.

New, M.B. 2002. Farming freshwater prawns. A manual for the culture of the giant river prawn (Macrobrachium rosenbergii). FAO Fisheries Technical Paper no. 428. FAO, Rome, Italy.

Nogueira, M. 2008. Estudo da qualidade dos efluentes gerados em diferentes fases do cultivo do camarãoda-amazônia Macrobrachium amazonicum. Tese de Doutorado, Universidade Estadual Paulista. São Paulo, Brasil.

Pereira, M. G., G. S. Valladares, L. H. C. Anjos, V. M. Benites, A. Espíndula Jr., and A. G. Ebeling. 2006. Organic carbon determination in histosols and soil horizons with high organic matter content from Brazil. Scientia Agricola 63:187-193. 
Preto, B. L., J. M. Kimpara, P. M. C. Moraes-Valenti, F. R. Tito Rosa, and W. C. Valenti. 2011. Production strategies for the short term grow-out of the Amazon River prawn Macrobrachium amazonicum (Heller, 1862) in ponds. Pan-American Journal of Aquatic Sciences $6: 1-8$.

Valenti, W. C., M. B. New, K. R. Salin, and J. Ye. 2010. Grow-out systems - monoculture. Pages 154-194 in M. B. New, W. C. Valenti, J. H.
Tidwell, L. R. D'Abramo, and M. N. Kutty, editors. Freshwater prawns: biology and farming. WileyBlackwell, Oxford, UK.

Valenti, W. C., L. A. Hayd, M. P. Vetorelli, and M. I. E. G. Martins. 2011. Economic analysis of Amazon River prawn farming to the markets for live bait and juveniles in Pantanal, Brazil. Boletim do Instituto de Pesca 37(2):165-176. 